\title{
Afet Farkındalık Eğitimlerinde Verimliliği Arttıran Modeller
}

\author{
G. Gülnaz GÜLTEKİN', Emel SONKAYA ${ }^{2 *}$ ve Burhan ULUTAŞ ${ }^{3}$
}

Öz

Türüne ve niteliğine bağlı olarak afetler önemli fiziksel, ekonomik ve sısyal kayıplara yol açar. Hazırlık, afetleri önlemenin temel yoludur. Afet ve Acil Durum Yönetimi Başkanlığı (AFAD), doğa olaylarının afetlere dönüşmesini önlemek amacıyla çeşitli hazırlık faaliyetler yürütmektedir. Örneğin, kamuoyunu bilinçlendirmek üzere 2003 yılında Ankara'da kurulan AFAD Deprem Simülasyon Merkezi'nde bugüne kadar her yaştan çok sayıda öğrenciye ve kamu personeline eğitim verilmiştir. AFAD'ın eğitimlerinde kullanılmak üzere eğitmenler tarafından özel tasarlanıp üretilmiş olan birçok model mevcuttur. Bu çalışmada depremin oluşum mekanizmasının ve gerçekleşme sürecinin gösterildiği "Yer Kabuğu Katman Modeli" ile "Üzerinde Yapı İnşa Edilebilen Deprem Sarsma Tablası Modeli"nin tasarım ve üretim süreçleri anlatılmaktadır. Afet farkındalık eğitimlerinde katılımcıların izleyici konumundan çıkıp sürece dâhil edilmesini sağlayan bu modeller ilgi uyandırmakta, soyut şeyleri somutlaştırmakta, zamandan tasarruf sağlamakta ve tekrar tekrar kullanılabilmektedir. Söz konusu modellerin çoğaltılarak ülkemizin her yerinde deprem farkındalık eğitimlerinde kullanılabileceği düşünülmektedir. Dolayısıyla, kolaylıkla modellenebilecek bu materyallerin intiyaç duyulan eğitim kurumlarında, sivil toplum ya da kamu kuruluşlarında üretilerek depremler konusunda daha çok insanın deneyime dayalı bilinçli hale gelmesi sağlanabilir.

Anahtar Kelimeler: Afet, deprem, farkındalık, eğitim modeli, sarsma tablası.

\section{The Models Which Raise Efficiency in Disaster Awareness Trainings}

\begin{abstract}
\footnotetext{
${ }^{1}$ Dr. Öğretim Üyesi, Ankara Hacı Bayram Veli Üniversitesi İletişim Fakültesi, ANKARA.

${ }^{2}$ Mühendis, Afet Eğitmeni. Afet ve Acil Durum Yönetimi Başkanlığı, ANKARA.

${ }^{3}$ Arama Kurtarma Teknisyeni, Afet Eğitmeni. Afet ve Acil Durum Yönetimi Başkanlığı, ANKARA

*ilgili yazar / Corresponding author: emel.sonkaya@afad.gov.tr

Gönderim Tarihi: 11.05.2019

Kabul Tarihi: 29.06.2019
}

Disasters, depending on the type and nature, cause significant physical, economic and social losses. Being ready for disasters is the most basic way to prevent or reduce the destruction caused by disasters. Disaster and Emergency Management Presidency (AFAD) carries out various activities in order to prevent the transformation of natural events into disasters. For example, AFAD Earthquake Simulation Center, which was established in Ankara in 2003 to raise public awareness, has trained many students and civil servants of all ages to date. There are many models specially designed and produced by instructors for use in AFAD's trainings. In this study, the design and production processes of the "Earth Shell Layer Model" and " Earthquake shock table model that can be building design on it" are explained. These models that enable participants to be included in the process and become involved in disaster awareness trainings; arouses interest, materializes abstract things, saves time and can be used again and again. It is thought that these models can be used in earthquake 
awareness training throughout Turkey. Therefore, these materials, which can be modeled easily, can be produced in needed educational institutions, civil society or public institutions and more people can become conscious about experience.

Keywords: Disasters, earthquake, awareness, training model, shaking table.

\section{Giriş}

Afetler, toplumun tamamı veya belli bir kesimi için fiziksel, ekonomik ve sosyal kayıplar doğuran, normal hayatı ve insan faaliyetlerini durduran veya kesintiye uğratan, etkilenen toplumun baş etme kapasitesinin yeterli olmadığı doğa, teknoloji veya insan kaynaklı olaylardır (Quarantelli, 1985). Afet, bir olayın kendisi değil, doğurduğu sonuç olarak değerlendirilmektedir (AFAD, 2014). Türkiye sahip olduğu tektonik, sismik, topografik ve iklimsel yapısı gereği doğal afetlerle sıklıkla karşı karşıya kalan bir ülke olup; su baskını, sel, çığ, heyelan, yangın ve en önemlisi depremlerde önemli kayıplar veren bir ülkedir. Depremlerde insan kaybı açısından dünyada üçüncü, etkilenen insan sayısı açısından sekizinci sırada olan ülkemizde her yıl büyüklüğü 5 ile 6 arasında değişen en az bir deprem yaşanmaktadır (AFAD, 2018; Guha-Sapir, 2011).

Türkiye, yeryüzünün en aktif deprem kuşaklarından birisi olan; Akdeniz, Alp, Himalaya deprem kuşağı içerisinde yer almaktadır. Türkiye'nin afetlerle ilgili istatistik verilerine bakıldığında, depremlerin en tahripkâr doğa kaynaklı afet sonucunu doğurduğu görülmektedir. 1902-2003 yılları arasında, Türkiye'de 137 adet hasarlı deprem meydana gelmiştir. Bu depremlerde 83.908 kişi hayatını kaybetmiş, 171.283 kişi yaralanmış ve 493.824 konut yıkılmış veya ağır hasar görmüştür (Ergünay, 2007). Afetlerde yaşanan can ve mal kayıplarının en aza indirilmesi, toplumun tüm kesimlerinin afetler konusunda bilinçlendirilmesiyle mümkündür. Doğa olaylarını önlemek imkânsız olsa da bunların afetlere dönüşmesinin bireysel sorumluluk ve toplumsal bilinç ile önlenebileceği konusunda toplumsal farkındalık oluşturmak gerekmektedir. Bu süreç yoğun çaba ve farklı yaklaşımlar gerektirmektedir.

Afet yönetiminde, can ve mal kayıplarının azaltılabilmesi için öncelikli olarak risk yönetimi yaklaşımı ele alınmalıdır. Ülkemizde yapılan çalışmalar daha çok afetlerden sonraki "müdahale" aşamasına yönelmiştir. Oysa afet yönetiminin amacı sadece insanları enkaz altından kurtarmak, hastaneye yetiştirmek gibi müdahale çalışmaları yapmak değildir. Aksine modern afet yönetimi, öncelikle insanları depremle beraber görülebilecek tüm tehlikelerden korumayı ve mevut riskleri afet olmadan önce azaltmayı esas alır. Modern afet yönetimi sisteminde afet öncesi korumaya yönelik çalışmalar "risk yönetimi", afet sonrası yapılan çalışmalar ise "kriz yönetimi" olarak adlandırılır. Risk yönetimine gerekli önem verilmezse, kriz yönetimi başarılı olamaz (Kadıoğlu, 2009). Afet yönetimi; afet öncesinde, sırasında ve sonrasında gerçekleştirilecek bir dizi faaliyeti kapsar. Özellikle depremler gibi doğal afetler, gerçekleştikleri coğrafya içinde tekrarlandıkları için, bu faaliyetleri birbirini izleyen döngüsel bir model içinde görmek mümkündür: 'Hazırlıklı olma', 'acil müdahale', 'iyileştirme' ve 'zarar azaltma' çalışmaları ayrı uzmanlıklar gerektiren ve birbirlerini tamamlayan alanlardır (Atlı, 2006). Bu çalışmanın ana teması depremlere hazırlıklı olma aşamasıyla ilgilidir. Hazırıklı olma aşaması, önceden birey ve aile düzeyinde hazırık ve plan yapmayı içermektedir. Bu bağlamda yediden yetmişe toplumun tüm kesimlerinin afete hazırlanması için gerekli eğitimlerin planlanması ve gerçekleştirilmesinin yanı sıra afet durumunda görev yapacakların, gönüllülerin, medyanın ve yöneticilerin eğitimini de kapsamaktadır (Baş, 2003).

Afet ve Acil Durum Yönetimi Başkanlığı (AFAD), afetlerin önlenmesi ve zararlarının azaltılması, afetlere müdahale edilmesi ve afet sonrasındaki iyileştirme çalışmalarının süratle 
tamamlanması amacıyla gereken faaliyetlerin planlanması, yönlendirilmesi, desteklenmesi, koordine edilmesi ve etkin uygulanması için ülkenin tüm kurum ve kuruluşları arasında işbirliğini sağlayan, çok yönlü, çok aktörlü, bu alanda kaynakların rasyonel kullanılmasını gözeten, faaliyetlerinde disiplinler arası çalışmayı esas alan, iş odaklı, esnek ve dinamik yapıda teşkil edilmiş bir kurumdur (AFAD, 2018). Afetleri önlemenin birinci ve en önemli ayağını eğitim oluşturmaktadır (Ivanov, 2014; UNICEF, 2011; Vaughter, 2016; Aghaei, 2018). Örgün ve yaygın eğitim programlarında müfredata yerleştirilen afet bilinci geliştirmeye yönelik bilgilendirme ve bilinçlendirme çalışmaları çoğu kez yetersiz kalmaktadır. Doğa olaylarının afete dönüşmesine yol açan davranışlar ve uygulamalar hakkında kamuoyunu bilinçlendirmek üzere 2003 yılında Ankara'da kurulan AFAD Deprem Simülasyon Merkezi'nde bugüne kadar her yaştan öğrenci ve kamu personeli olmak üzere çok sayıda kişiye eğitim verilmiştir (AFAD) 2016 yılında başlayan "Afete Hazır Türkiye Eğitim ve Bilinçlendirme Kampanyası" kapsamındaki 'Afete Hazır Okul' modülü ile önlem almak için 'harekete geçen okullar' modeli hayata geçirilmiştir. Bu modelde AFAD Eğitmenleri Deprem Simülasyon Merkezi'nde 'temel afet bilinci' verdikleri okulları, bir ay sonra afet hazırlıklarını yerinde görmek için ziyaret etmekte; böylece eğitimlerin verimliliğini belirlerken katılımcı sayısını değil, 'harekete geçen okulları' baz almaktadırlar (AFAD, Mart 2016).

AFAD Deprem Simülasyon Merkezi'nde 2003 yılından beri kurumların ve okul gruplarının katıımı ile özellikle deprem odaklı olarak "önlem alırsak zarar görmeyiz" kültürünü yaygınlaştırıcı faaliyetler yapılmaktadır. Bu farkındalık oluşturma çalışmalarında depremin aslında sıradan bir doğa olayı olduğu ancak önlem almadığımız zaman afete dönüştüğü vurgulanmaktadır. Eğitim etkinliklerinde depremlerin oluşum mekanizmasının zihinlerde somutlaşabilmesine yönelik özgün olarak tasarlanmış modeller kullanılmaktadır. Öğrenmeöğretme sürecinde doğru araç gereçlerin kullanılmasının öneminden hareketle, AFAD Deprem Simülasyon Merkezi bünyesinde, bizzat AFAD çalışanları tarafından üretilmiş çok sayıda model, her geçen gün daha da geliştirilerek zengin öğrenme ortamları oluşturmada kullanımaktadır.

AFAD deprem eğitimi faaliyetlerinin planlanması ve uygulanmasında, eğitim dünyasındaki yönelim ve değişimler dikkate alınmaktadır. Bu bağlamda 21. yüzyılda öğrenme/öğretme süreçlerini etkileyen yapılandırmacılık, probleme dayalı öğrenme, iş birliğine dayalı öğrenme, etkin öğrenme, tam öğrenme gibi yaklaşımlardan afet farkındalık eğitimlerinde yararlanılmasına özen gösterilmektedir.

Öğrenenin bilgiyi bireysel ve sosyal olarak kendisinin oluşturduğunu kabul eden yapılandırmacı görüş; üretici öğrenme, keşfederek öğrenme ve duruma bağlı öğrenme gibi teorilerin bir araya gelmesiyle oluşmuştur. Yapılandırmacılıktaki vurgu, öğreticiden çok öğrenen üzerinedir. Yapılandırmacı süreç öğrenenlere deneyimsel öğrenme ortamları sunar. Ve bu ortamlar aktif katılım, inisiyatif kullanma, öğrenme sürecini değerlendirme ve birinci elden deneyim kazanma fırsatlarını içerir (Özden, 2011) Etkin öğrenme ya da diğer adıyla deneysel öğrenme aynı zamanda yaparak öğrenme anlamına da gelmektedir. Etkin öğrenme sürecinde öğrenenler, dinlemekten çok katılımcı durumundadır. Bilginin aktarılmasına daha az, öğrenen becerilerinin geliştirilmesine ve öğrenenlerin etkinliklerde yer almasına daha çok önem verilir (Şahinel, 2011) Afet farkındalık eğitimlerinde katılımcıların sürece dâhil edilmesi özellikle önemli ve gerekli görülmektedir. Zira, hedef kitlenin sadece katılımcı, izleyici konumunda olmayıp sürece dâhil olması, bu sürecin başarısını olumlu yönde etkilemektedir. Ayrıca mesajların özelikle çocuk ve genç gruplarda somutlaştırılması için modeller ve materyaller kullanılması bir takım halinde kullanııması gereklilik olarak karşımıza çıkmaktadır.

İşbirliğine dayalı öğrenme (Dansereau, 1988) öğrenenlerin ortak öğrenme hedeflerini gerçekleştirmek için küçük gruplar halinde birlikte çalıştıkları öğretimsel süreçleri anlatan bir kavramdır. Takımın iyi bir sonuç elde etmesi, her bir üyenin performansına ve belirli 
dereceye kadar birbirlerine yardım etmelerine bağlıdır (Ekinci, 2011). İşbirliğine dayalı öğrenme yönteminin etkin kullanıldığı uygulamalardan biri çocuklarla yapılan ve "tiyatro ile bilinçlenme" çalışmasıdır. Bu etkinlikte senaryonun çocuklarla birlikte yazılması (çocuklara, kendilerini izleyecek olanlara hangi mesajın verilmesi gerektiği anlatılıp sorumluluk verilerek ana fikre odaklanmalarının sağlanması) ve oyunu yine çocukların oynaması; izleyenlerin dâhil edildiği interaktif bir gösteri yapmaları ve tiyatro sonrasındaki yaşam sürecinde de sorumluluklarının devam ettiği bilincinin aşılanması iş birliğine dayalı yaklaşımının bir örneğidir (AFAD, 31 Mayıs 2016).

Öğrenme sürecinde doğru araç gereçlerin kullanımının sayısız yararı vardır. Araç gereçler etkili öğrenme ortamları oluşturmayı sağlar. Soyut şeyleri somutlaştırırlar, ilgileri uyarırlar, zamandan tasarruf sağlarlar, tekrar tekrar kullanılabilirler, içeriği basitleştirerek anlaşıımalarını kolaylaştıırlar. Ayrıca; öğrenenlerin farklı öğrenme stillerini desteklemeye ve intiyaçlarını karşılamaya yardımcı olurlar, gözlem ve deneyim yoluyla öğrenmeyi pekiştirirler (Yalın, 2004). Deneyime dayalı; gözlemleyerek, yaparak, yaşayarak öğrenmenin etkililiği ve değeri üzerine yapılmış sayısız araştırma vardır. Özellikle fen ve teknoloji öğretim programlarının başarısı için eğitim sürecinde materyal kullanımı yaşamsal derecede önemlidir. Eğitimde materyal kullanımı, etkili bir öğretim ortamı yoluyla öğrencilerin hedeflere ulaşmasında ve yürütülen programın başarılı olmasında önemli bir rol oynar. Öğretim yöntem ve teknikleriyle çok iyi kombine edilmiş görsel materyal kullanımı algılamayı ve öğrenmeyi kolaylaştırır, unutmayı azaltır ve hatırlamayı sağlar. Ayrıca yanına gidilmesi ya da sınıfa taşınması mümkün olmayan olay, olgu ve varlıkları sınıfa taşır (Yaşar, 2004:108). Bir öğrenme etkinliği ne kadar çok duyu organına hitap ederse öğrenme olayı o kadar iyi ve kalıcı izli olmakta, unutma gecikmektedir. ABD Texas Üniversitesi'nde Philips tarafından yapılan araştırma sonuçlarına göre, zaman faktörü sabit tutulduğunda hatırlama şu yüzdelerle olmaktadır: İnsanlar okuduklarının \%10'unu, duyduklarının \%20'sini, gördüklerinin \%30'unu hem görüp hem duyduklarının \%50'sini, görüp işittikleri ve söylediklerinin \%80'ini, görüp işitip dokunup söylediklerinin \%90'ını hatırlamaktadırlar (Demirel, 2012). Dolayısıyla katılımcıların sürecin tamamına dahil edilmesi, algılanan şeylerin zenginliği, süreci sahiplenmelerinin sağlanması özel önem arz etmektedir. Farklı gruplar için eğitimlere (farklı detaylar) ilaveler yapılmaktadır. Küçük gruplar için eğitimler tamamen oyun ve müzikten oluşturulmakta, işitme engelli gruplar için eğitimlerde işaret dili kullanılmakta, görme engellilerin eğitimlerinde dokunsal öğelerin, materyallerin en yüksek düzeyde olmasına dikkat edilmekte, bedensel engellilerin her faaliyete kolaylıkla katılımı sağlanmakta, genç gruplarda yaşanmışlıklar ilgi çekici olmakta, yetişkinlerin sosyal durumlarına göre farklı eğitim yöntemleri kullanılmaktadır. Ayrıca işitme engellli öğrencilere işaret dili ile ilk afet eğitimi AFAD Deprem Simülasyon Merkezi'nde gerçekleştirilmiş olup (https://www.afad.gov.tr/tr/1547/AFAD-Engel-Tanimiyor) bu eğitimler sonrasında çocuklardan yine olumlu geri bildirimler alınmış özellikle işitme engelli çocukların sürece dahil edilmiş olmanın ve hatta süreçte başrol oynuyor olmanın güzel bir örneği olarak literatüre geçmiştir.

AFAD'ın eğitimlerinde eğitmenler tarafından afet eğitimleri için özel tasarlanıp üretilmiş olan birçok materyal kullanılmakta olup, bugüne kadar ortaya çıkan tecrübeler, katılımcıların en çok ilgisini çeken modellerden ikisinin depremin oluşum mekanizmasının ve gerçekleşme sürecinin gösterildiği "Yer Kabuğu Katman Modeli" ile "Üzerinde Yapı İnşa Edilebilen Deprem Sarsma Tablası Modeli" olduğunu ortaya koymaktadır.

AFAD eğitimlerinin sonunda katılımcıların öğrenme deneyimleriyle ilgili değerlendirmelerini, görüş ve önerilerini almak üzere anketler başta olmak üzere çeşitli geri bildirim çalışmaları yapılmaktadır. Bundan başka, AFAD Eğitim Merkezi'nden yararlanan eğitim kurumlarına AFAD eğitim uzmanları tarafından ziyaretler gerçekleştirilmekte ve geri bildirimler alınmaktadır. Bu çerçevede gerek anketlerden elde edilen veriler gerekse ziyaretler 
sırasındaki görüşmelerde alınan geri bildirimler; depremin oluşum mekanizmasının ve deprem sırasında neler yaşandığının zihinlerde somutlaşmasını sağlamak amacıyla üretilen bu iki modelin katılımcılar üzerinde somut etki yarattığını ortaya koymaktadır. Bundan başka, AFAD Eğitim Merkezi'ni ziyaret ederek, burada kullanılan eğitim-öğretim yaklaşımları ile araç-gereçlerini inceleyip deneyimleyen Hacettepe Üniversitesi Jeoloji Mühendisliği ve Ankara Üniversitesi Jeofizik Mühendisliği Bölümlerinin öğretim elemanları ve öğrencileri de bu tür modellerin yerbilimleri ile ilgili fakültelerde de kullanılabileceğini ifade etmektedirler.

Bu çerçevede, adı geçen modellerin çoğaltılarak ülkemizin her yerinde deprem farkındalık eğitimlerinde kullanılabileceği öngörüsünden hareketle bu makalede, AFAD Deprem Simülasyon Merkezi bünyesinde geliştirilen ve gerek merkezde gerekse gezici eğitimlerde kullanılan "Yer Kabuğu Katman Modeli" ve "Üzerinde Yapı İnşa Edilebilen Deprem Sarsma Tablası Modeli"nin üretim süreçleri ve eğitimlerde kullanımları hakkında bilgi verilmektedir. Amaç, kolaylıkla modellenebilecek bu materyallerin ihtiyaç duyulan eğitim kurumlarında, sivil toplum kuruluşlarında ya da kamu kuruluşlarında üretilerek depremler konusunda daha çok insanın deneyime dayalı bilinçli hale gelmesine katkı vermektir.

\section{Yöntem}

\subsection{AFAD deprem simülasyon merkezinde üretilen örnek iki eğitim materyali ve eğitim uygulamaları}

\subsubsection{Yerkabuğu katman modeli}

$\mathrm{Bu}$ model özgün bir şekilde tasarlanmış olup katmanlar altındaki magmanın modellenebilmesi için birçok madde denenmiştir. Deneme yanılma çalışmaları sonucunda hava aldığında kurumayan, kıvam ve gerçekçilik bakımından magmaya en çok benzeyen malzeme çeşitli maddelerin karışımı ile oluşturulmuştur. Bu malzemeler; \%85 açık kahverengi renkte jel kıvamında arapsabunu, \%5 kum ve toprak, \%2 kırmızı yağlı boya, \%5 ponza talaşı ve çapı yaklaşık $1 \mathrm{~cm}$ boyutlarında ponza taşları, \%2 pigment fosfor tozu, $\% 1$ kırmızı floresan (fosforlu) sprey boyadır. Malzemeler karıştırılarak magma görüntüsü elde edilmiştir. Magma üzerine yerleştirilen straforlar dünyanın katmanları şeklinde boyanarak üzerine sıcak silikon ile toprak ve hafif taş yapıştırılmıştır. En üste yeryüzü şeklinde düzenlenen katman yerleştirilmiş; katmanlardaki çatlaktan magma rengindeki boya ve hamur ile yanardağ oluşumu da modellenmiştir. 

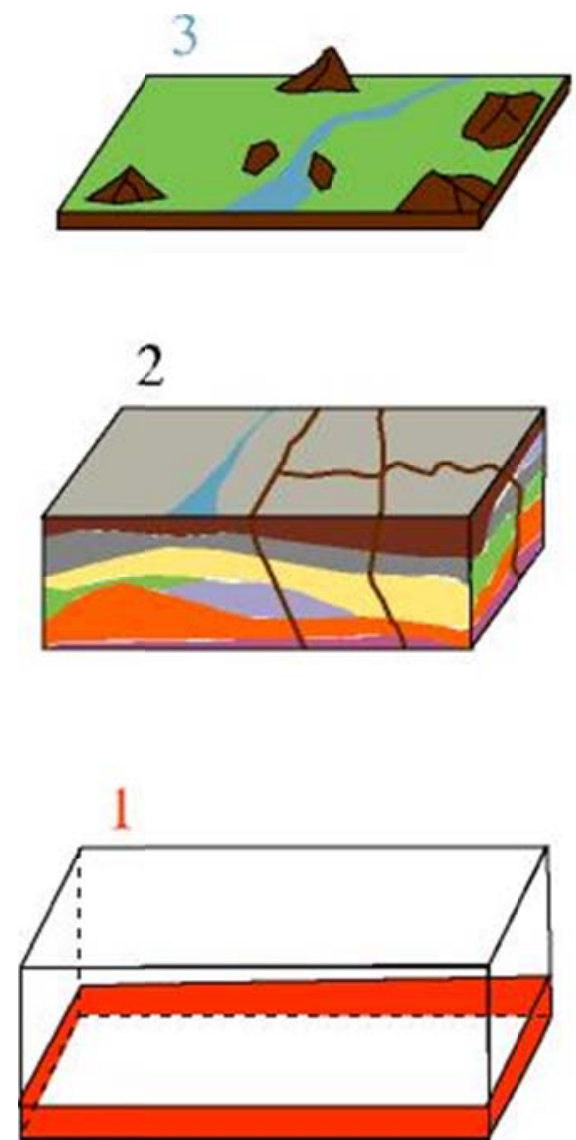

Resim 1. Yerkabuğu modeli taslak çizim

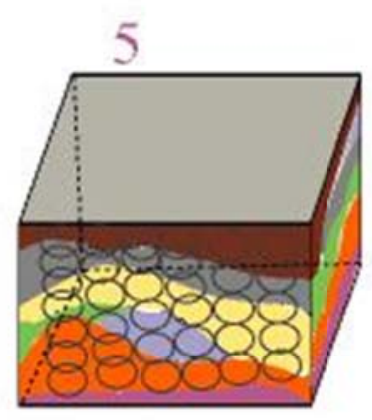

I Dizenek sergi faunusu

2 Dijicnek ycraltı katmanları

3 Doğal yeryüzü maketi

4 Hareketli şehir maketi

5 Deprem oluşum hareketi

Yerkabuğu katmanlarını göstermek için iki ayrı model hazırlanmıştır. İlk modelde magmanın akıcı ve kıvamlı olabilmesi için silikon malzeme ile yapılan deneylerde; silikonun yüzeyinde 30 dakika içinde bir zar oluştuğu, üstü şeffaf naylon ile kaplansa bile kuruyarak akışkanlığını kaybettiği gözlenmiştir. Aynı işlem çeşitli jöle ve jellerle denenmiş ama içerisindeki kimyasallar nedeniyle hepsi farklı sürelerde kurumuş veya renklendirme aşamasında özelliklerini kaybetmişlerdir.

Mini elektrikli kompresör hava hortumları ve hava taşıyla birlikte kullanılarak hava kabarcıkları oluşturulmuş, bu sayede magmanın hareketli ve kaynayan yapısının bir benzeri elde edilmiştir. 5-7 psi basınç üreten motorların ürettiği hava kabarcıkları yetersiz gelmiş; kaynama simülesi (benzetimi) yapılamamış, ancak 25-30 psi basınçlar üreten elektrikli kompresör hava hortumları ve hava taşıyla birlikte çıkan hava kabarcıkları magmayı simüle eden maddeye kaynıyormuş görüntüsü vermiştir. Katı katmanların modellenmesinde denenen tek parça straforlar, sertlik dereceleri düşük olduğundan işleme ve boyama sürecinde dağıldıkları ve tinerin etkisi ile aşırı eridikleri için uygun olmamışlardır. Daha sonra sertlik derecesi en yüksek olan $5 \mathrm{~cm}$. kalınlıktaki straforlar üst üste yapıştırılarak istenilen boyut elde edilmiş, ardından levhaları temsil edecek parçalara ayrılmıştır. Parçalara ayrılırken tamamen düzgün yani kalıp gibi olmayacak şekilde yani birbirleriyle etkileşimleri görülebilecek şekilde olmalarına dikkat edilmiştir. Yeryüzü katmanlarının gösterilebilmesi için modeller farklı renklerde boyanmıştır. Doğal görünüm verilebilmesi içinse straforların bazı kısımları Resim 2.'de görüldüğü gibi tiner ile eritilmiş, oluşturulan çukurlara taş ve toprak sıcak silikon ile yapıştırılmıştır. 


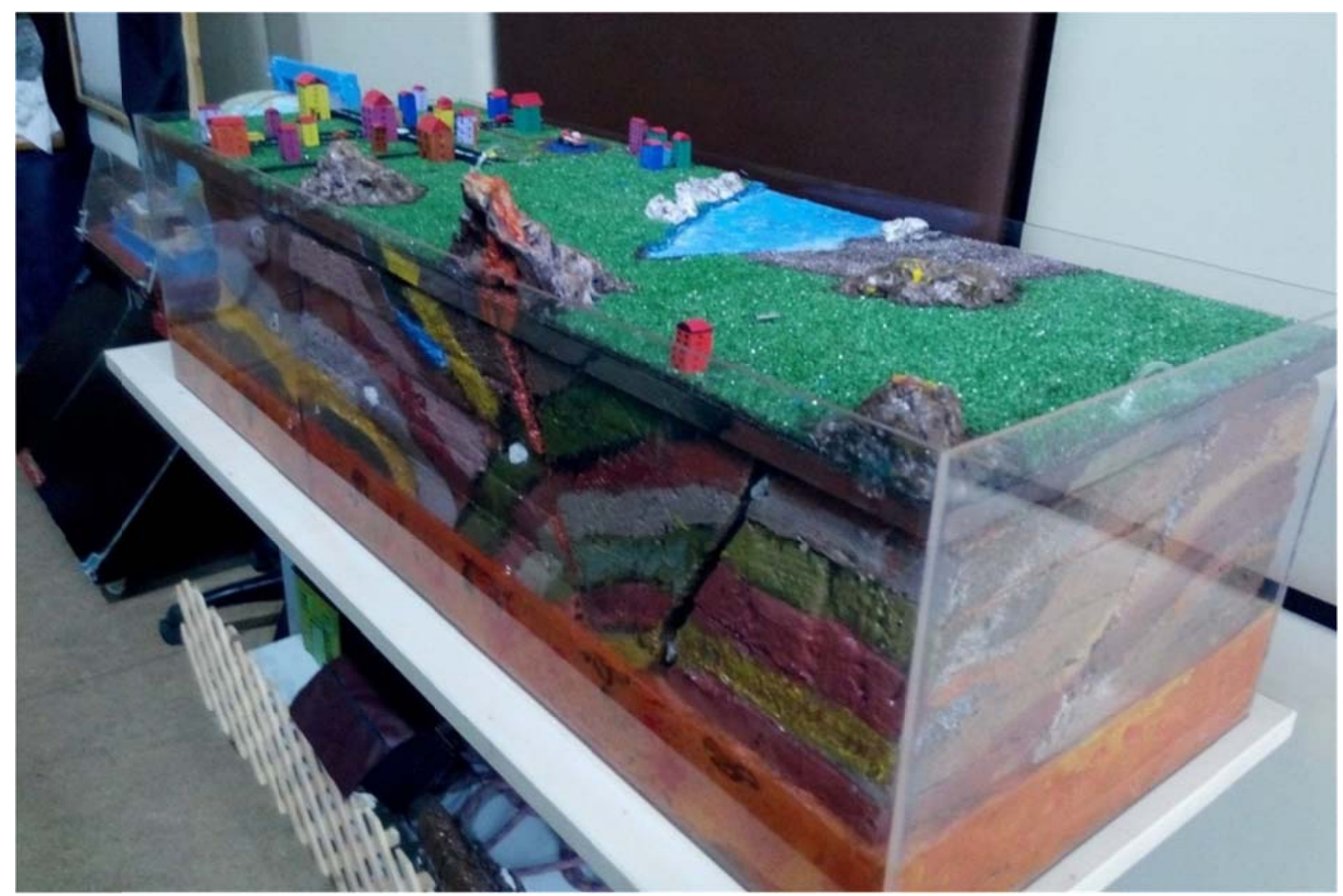

Resim 2. Faunus içindeki yerkabuğu (dünyanın katmanları) modeli

Modelin üstüne toprak örtüsünün gösterildiği bir katman yapılarak "ayağımızı bastığımız yeryüzü kesintisiz ve bütün gibi görünse de derinlere indiğimiz zaman yeryüzünün sandığımız gibi kesintisiz bütün olmadığı, tıpkı yap-boz gibi parçalardan (levha) oluştuğu" bilgisinin modellenmesi amaçlanmıştır. Yeryüzü tabakasının gerçeğe uygun olması amacı ile topoğrafik şekiller (tepeler, vadiler, gölet) ve mahalle maketleri eklenmiştir. Bütün bu modeller $5 \mathrm{~mm}$ kalınlığında pleksiglas bir şeffaf bir fanusa yerleştirilmiştir. Yine şeffaf bir bölme ile ayrılan kısımda depremin "P" dalgası, içinde yaylar olan ve diğer kısımdaki tabakalar şeklinde boyanmış likralı esnek kumaş ile modellenmiştir. P dalgasının gösterilmesi sırasında uygulanan kuvvet, katmanların magma içine gömülmesine sebep olmasın diye $P$ dalgasının modellendiği kısımda magma serbest bırakılmamış; üstüne yine şeffaf sert pleksiglas yerleştirilmiştir. Basıncın soğurulması için magma içerisine ayaklar yerleştirilmiştir. Model, tekerlekli bir masa üzerine kaymayacak şekilde sabitlenmiş ve kullanıma hazır hale getirilmiştir.

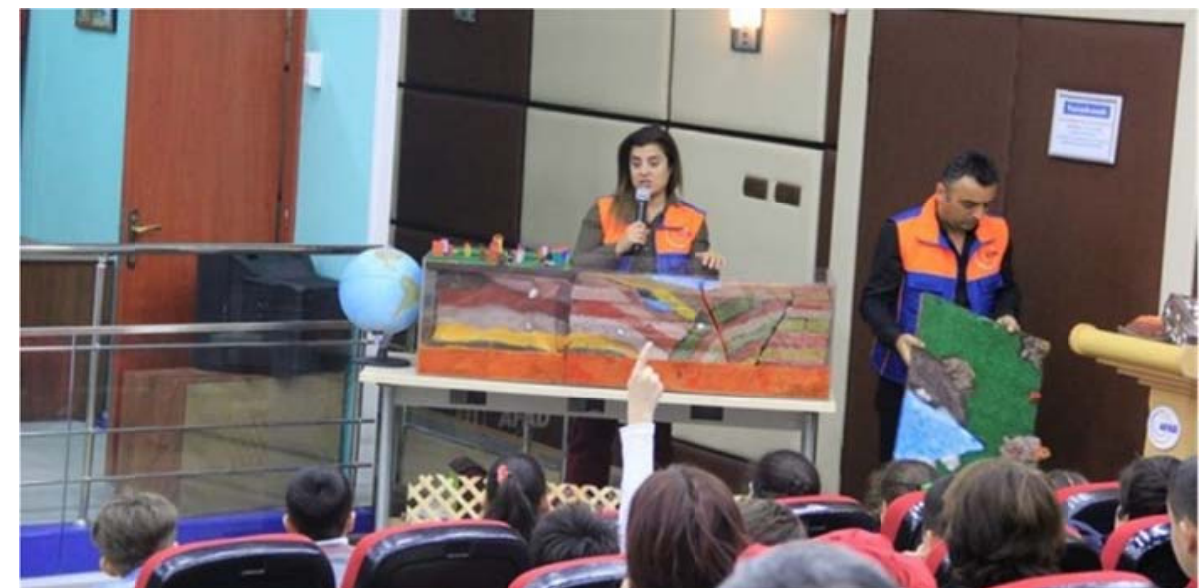

Resim 3. İlk olarak yapılan yer kabuğu katman modelinin AFAD eğitimlerinde kullanımı 
İlk modelin daha da gelişmişi olan ikinci modelde şu değişikliklere yer verilmiştir: Modelin daha hafif olması için magma eriyiği tüm fanus içine yayılmamış; fanusunı içinde, tüm fanusu kenardan dolaşan bir kanalın içine yerleştirilmiştir. Bu ikinci modelde magma, $8 \mathrm{~cm}$ yüksekliğinde ve dış kısımla $4 \mathrm{~cm}$ aralıklı kanalın içinde yer almış, katmanlar altında kalan orta kısma konulmamıştır. Model etkileşimli olduğu için yap-boz şeklinde levhaların anlaşılabilmesi için bazı katmanlar Resim 4'deki gibi fanustan çıkarılarak depremin oluşma sürecindeki hareketler bu katmanlar ile canlandırılmaktadır.

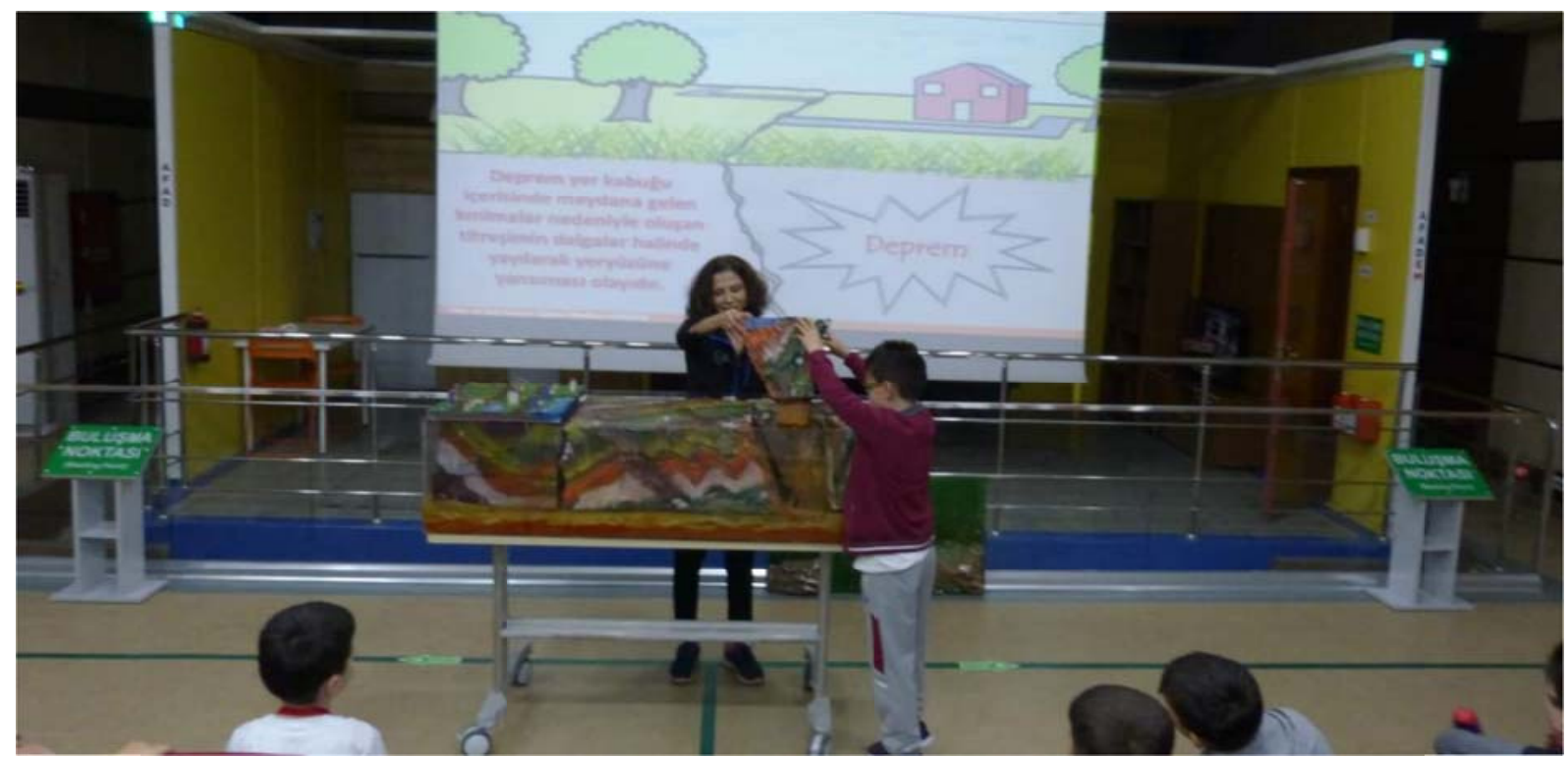

Resim 4. Yer kabuğu katmanları için hazırlanan ikinci modelin afet eğitimleri sırasında kullanımı; bazı katmanlar fanustan çıkarılabiliyor.

Kaldırılacak katmanların altı için şeffaf havuzlar $(20 \times 20 \mathrm{~cm})$ yaptırılarak magma ile doldurulmuş böylece kaldırılan katmanların altında da magma var görünümü oluşturulmuştur. Böylece katı, yarı eriyik ve eriyik tabakaların birbiriyle teması simüle edilmiştir. $P$ dalgasının gösterilebilmesi için bu kez HLB sünger kullanılmıştır. Fanusun kalınlığı bu kez $(10 \mathrm{~mm}$ olacak şekilde) arttırılmıştır.

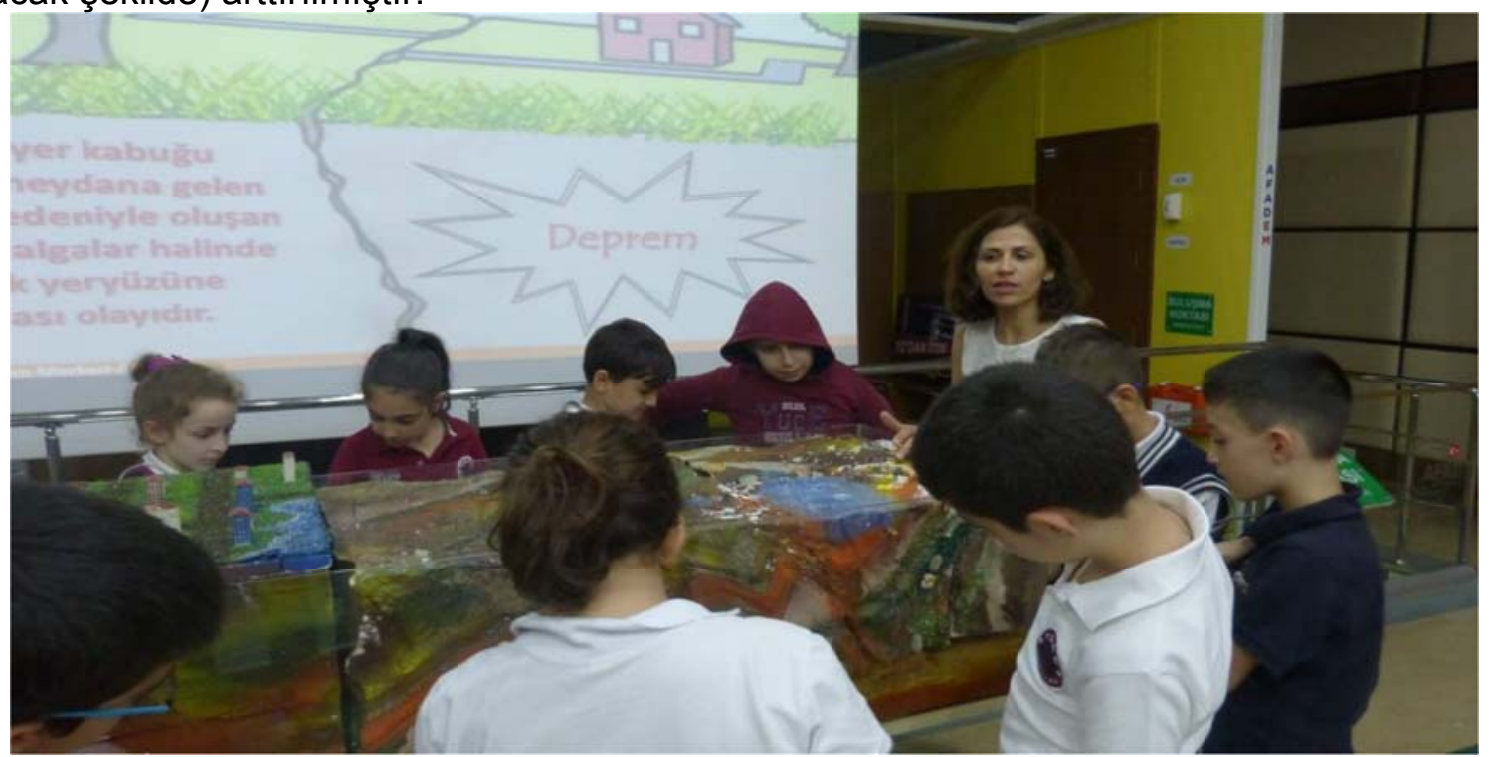

Resim 5. Faunus içindeki ikinci yer kabuğu modeli öğrenciler tarafından incelenirken 


\subsubsection{Dünyanın katmanları modeliyle ders senaryoları}

Kullanım kolaylığı açısından tekerlekli bir masa üzerinde kaymayacak şekilde, gerekirse köşelerinden sabitleme aparatları ile tutturarak kullanılması uygundur. Okul laboratuvarları ve sınıflar için bu modelin daha küçükleri ve plastik bir kova içinde düzenlenmiş olanları yapılabilir.

Üzerinde Yapı İnşa Edilebilen Deprem Sarsma Tablası Modeli: Afet bilinci eğitimlerinin en önemli vurgusu, yapıların deprem karşısındaki davranışlarının kurallara uygun yapılmaları ile ilgili olduğudur. Bu model, binaların sağlam olduğunda yıkılmayacağı gerçeğini, özellikle öğrencilerin zihinlerinde somutlaştırmak ve bu gerçekliği güvenli bir ortamda deneyimlemelerini sağlamak için oluşturulmuş etkileşimli bir düzenektir. Düzenek, eksik malzeme ile kurallara uygun yapılmayan ev maketlerinin yıkıldığının, yeterli ve uygun malzeme ile kurallara uygun yapılan ev maketlerinin ise sallama tablası üzerinde denenebilecek en büyük depremlerde bile yıkılmadığının gözlenmesine imkân verecek şekilde tasarlanmıştır. Düzenek, üzerinde evler inşa edilebilecek şekilde yapılmış mini bir mahalle görünümündeki sallanan bir tabladır. Ayrıca, ev oluşturabilmek için gerekli malzemeler düzeneğe dâhil edilmiştir. Eğitimi desteklemek ve öğrencilerde merak uyandırmak amacıyla gizli temel bölümleri de planlanmıştır.

Sallanan tabla üzerinde binalara temel olarak kullanılmak üzere iki kare çukur açılmıştır. Bu kare çukurlar, çıkarılan malzeme ile açılıp-kapanabilecek şekilde oluşturulmuş olup, üstleri çim halı ile kaplanarak temel hazneleri gizlenmiş ve böylece hemen keşfedilemez hale getirilmiştir.

Düzeneğin tasarım aşamasında hedef kitlenin yaş aralığı, ortalama boyları, uygulayabilecekleri kuvvet, kullanılan malzemelerin güvenliği, çocuk sağlığına zararlı malzeme kullanımaması, hedef kitlenin motor beceri kapasitesinin kullanımına yeterli olması, tablanın taşınabilir ve kolay yer değiştirebilir olması, şık ve gerçeğe uygunluk, ilgi çekicilik, merak uyandırıcı olabilmesi gibi hususlar göz önünde bulundurulmuştur. Bilgi ve tecrübelerin ışığında Resim 6'da görüldüğü gibi taslak çizimler yapılmıştır. 


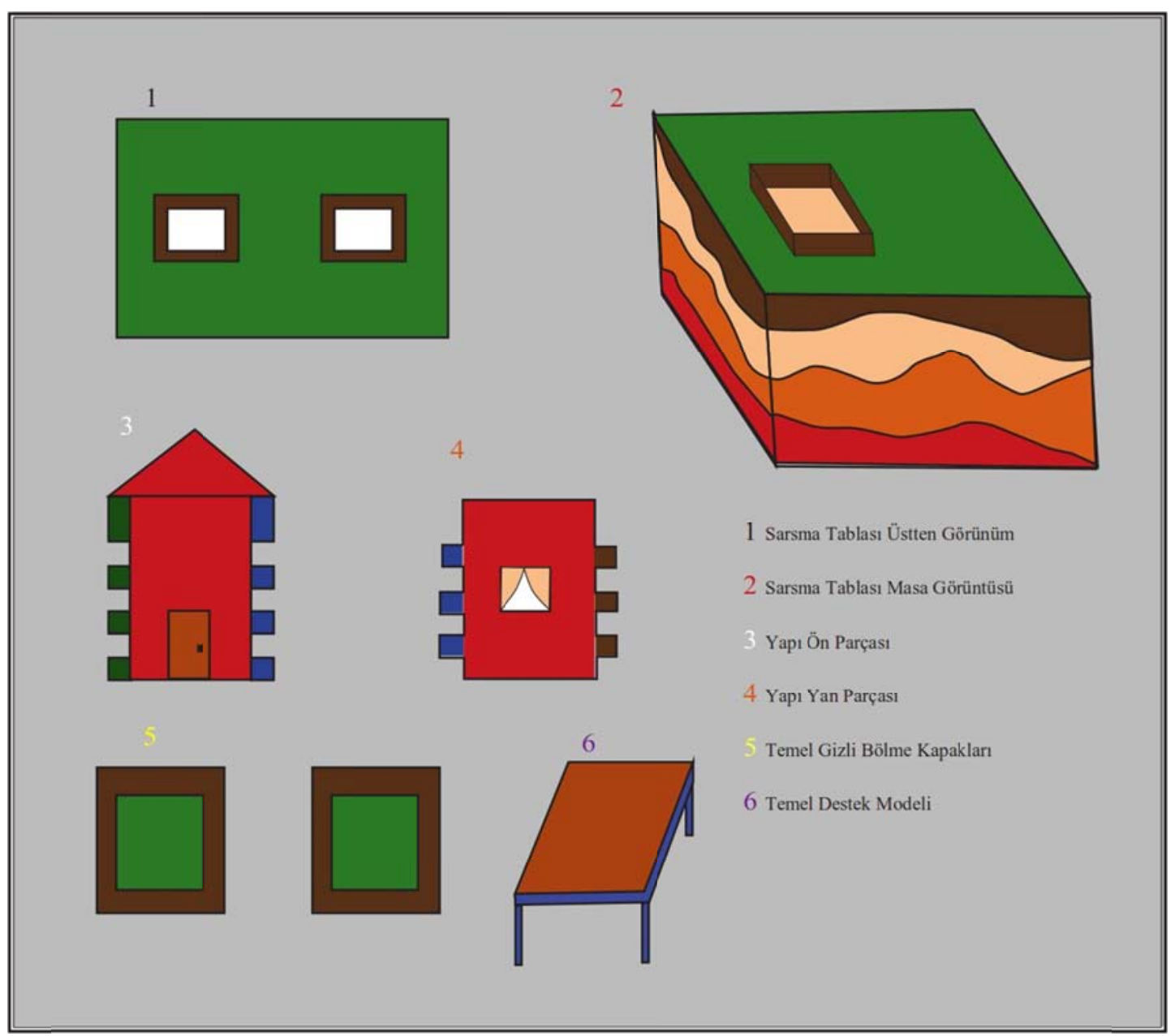

Resim 6. Deprem sarsma tablası modeli taslak çizimi

Ölçeklendirme çalışmaları ise yapı temel boşluğunda kullanılacak malzemelerin el ile doldurulabilmesi, temel dolgusu kullanılmayan yapıların yan yatıp devrilebilmesine imkân verecek temel boşluğunun oluşturulması, tabla ve yapıların orantılı olması, kullanılan malzemenin dayanım ve salınımına göre yapılmıştır. Düzenek, kısa boylu ya da tekerlekli sandalye kullanan bireylerin tabla üzerindeki her noktaya erişebileceği şekilde tasarlanmıştır; tablanın bağlı olduğu masa boyu ayarlanabilmektedir.

Düzeneğin yapım aşamasında tabla için önce doğal masif çam levha (30Sağlam yapı ön görünüm x50x70mm) denenmiş ancak bu malzemede temel boşluğunun açılması sırasında çatlakların oluştuğu ve ağırlığının da planlananın üstünde olduğu görülmüştür. İkinci olarak sunta lam levhalar denenmiştir. Tabla için kesilen sunta lam levhalar yüksek baskı uygulamalarında bağlantı yerlerinden dağılmışlardır. Denemeler sonunda tabla ve yapı malzemelerinin üretiminde $18 \mathrm{~mm} \times 70 \mathrm{~cm} \times 140 \mathrm{~cm}$ ebatlarında $\mathrm{MDF}^{4}$ levhalara karar verilmiş ve bu levhaların kalınlık değerlerinin belirlenmesi yine AR-GE çalışmalarıyla sağlanmıştır.

Deprem salınım ve sarsıntılarının öğrencilere uygulamalı olarak gösterilebilmesi ve kendi depremlerini yapabilmeleri için tabla ve masa arasına yay konulmuştur. Yaylar (kalem, konik, düz, tel yay, helezon, baskı) özel yay çeken atölyelerde pek çok denemeler sonucu elde edilmiştir. Yayların uzunluğu, et kalınlığı, şekilleri, genişliği hesaplanırken tabla ağırlığı

\footnotetext{
${ }^{4}$ MDF (İngilizce: Medium Density Fiberboard), sert veya yumuşak ahşap kalıntılarını parçalayıp ahşap life çevirdikden sonra, yüksek ısı ve basınç altında mum ve reçine tutkal ile oluşan levha şeklinde tasarlanmış ahşap ürün.
} 
karşısındaki esneme oranı, yatay salınımı ve öğrencilerin uygulayacağı kuvvet oranları hesaplanarak çeşitli denemeler yapılmıştır. Denemeler sonucunda $3 \mathrm{~mm} \times 5 \mathrm{~cm} \times 15 \mathrm{~cm}$ baskı yayın aranılan özelliklere sahip olduğuna karar verilmiştir. Yayların masa bağlantıları, cıvata ve kelebek somunlarla birleştirilmiştir.

Model, taşıma kolaylığı sağlanması açısından tekerlekli bir masa üzerine yerleştirilip sabitlenerek, masa çevresi yeraltı katmanları görselleriyle çevrelenmiştir.

Tabla üzerine inşa edilecek yapılar (ev modelleri) için $18 \mathrm{~mm} \times 70 \mathrm{~cm} \times 140 \mathrm{~cm}$ ebatlarında MDF levhalar kullanılmış; kullanıcı gruplarının öğrenciler olacağı göz önünde bulundurarak pürüzsüz yüzeyler elde edilmesi amacıyla tüm kesim yerleri zımparalanmıştır. Maket yapının dış duvarlarını oluşturacak malzemelerin kenarları birbirine geçecek şekilde girintili çıkıntılı yapılmıştır. Bu girinti çıkıntılara en üst kısımlarından dikey olarak kanal açılmıştır. Bu kanallar kurallara uygun inşa edilecek yapılarda pimler ile birleştirilecek; pimler kesişen duvarları birbirine bağlayacaktır.

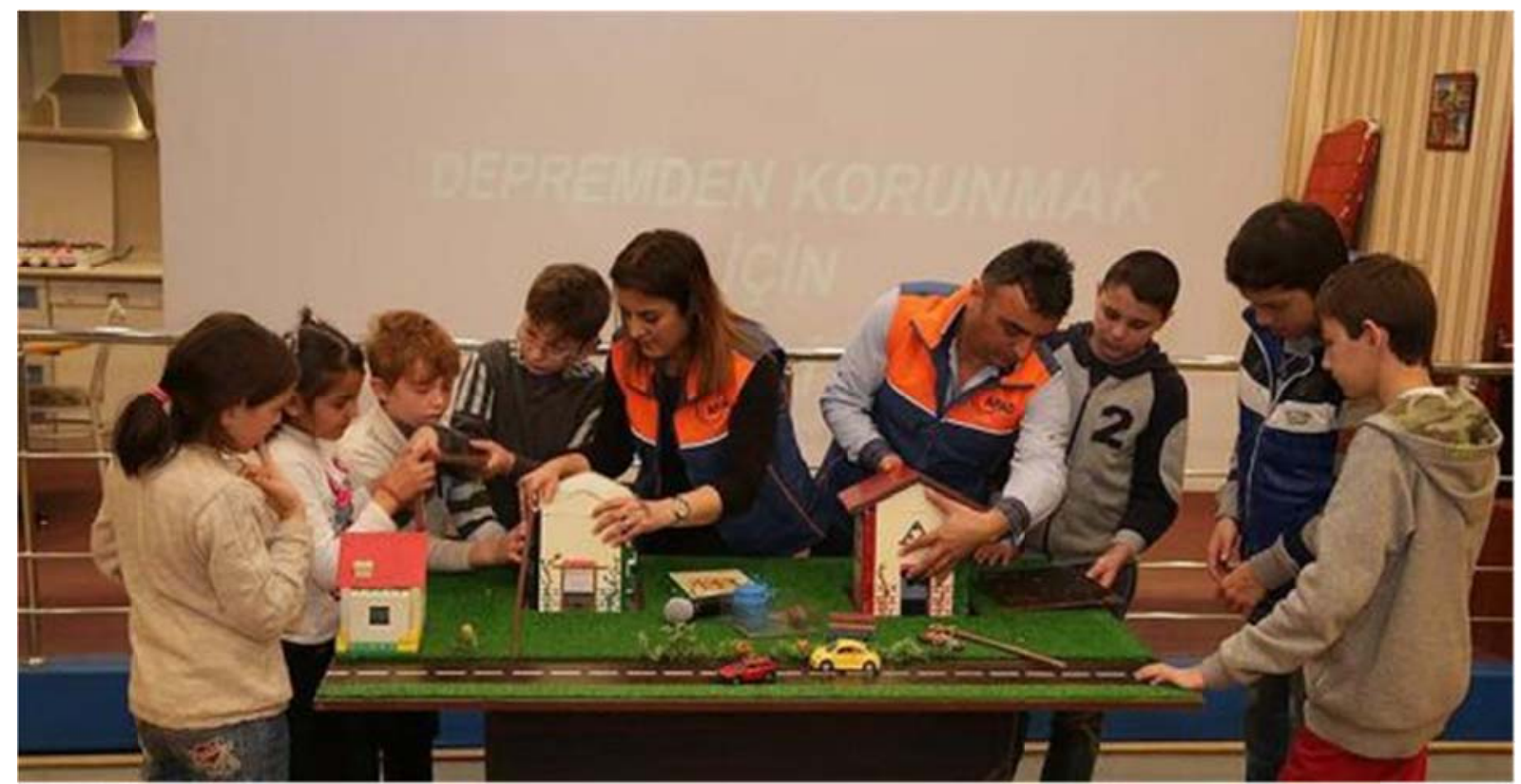

Resim 7. İlköğretim çağı çocuklarla tabla üzerinde gerçekleştirilen eğitimlerden bir görüntü

Bağlantı noktaları için kullanılacak pimlerin (metal, plastik, alüminyum, alaşım malzemelerden) ucu yarı konik hale getirilerek bağlantı kolaylığı ve kullanım güvenliği sağlanmıştır. Küçük yaş gruplarında demir görünümlü plastik pim kullanılması daha uygundur. Yapıların her bir bağlantı köşesi farklı renkte boyanarak kullanım kolaylığı ve renkli bir görüntü sağlanmıştır. Boya olarak çocuk sağlığına zararlı olmayan guaj boya kullanılmıştır. Tablanın üst kısmı doğal görünüm sağlaması amacıyla Resim 7'de görüldüğü gibi, suni çim ile kaplanarak üzerine araç yolları, maket ağaçlar, bahçe çitleri, elektrik direkleri ve araçlar yerleştirilmiştir.

Pimler tabla üzerinde sabitlenmiş depo görünümlü maket yapıda bulunmaktadır. Ayrıca temel ve yapı arasındaki boşluklarda dolgu oluşturmak amacıyla etkinlik sırasında "çimento veya beton" diye adlandırılacak olan sertleşip, yapışmayan özellikte oyun hamuru da depoda bulunmaktadır. Evlerin çatılarının iç taraflarına yapılan plastik kanallarla, sallantıda çatının evden ayrılmaması sağlanmaya çalışılmıştır. Faaliyetler sırasında yaşanan tecrübeler değerlendirilerek çatıların eve bağlantısı güçlendirilmiş, bunun için de pimler kullanılmıştır. Yapılan bu sallama tablasının sınıf ortamları için katlanabilir, taşınabilir ve çanta haline gelen modeli de hazırlanmış olup eğitimlerde kullanılmaktadır. 


\subsubsection{Sarsma tablası ile ders senaryoları}

Katılımcıların etkinliğe en üst düzeyde odaklanabilmeleri ve etkinliğe heyecan katılabilmesi için bir yarışma planlanmıştır. Katılımcılar iki gruba ayrılarak, her iki grubu temsilen 4 öğrenci etkinliğe davet edilmektedir. Diğer öğrencilerin ise izlerken katılmaları sağlanmaktadır. Etkinlik sırasında gerçek hayat drama yöntemleriyle taklit edilmekte; iki öğrenci evi yaparken, diğer iki öğrenci denetim mühendisi olarak yapımı takip etmektedir.

Çocuklar evleri inşa ettikten sonra denetim firması mühendislerine evler incelettirilerek "oturma izni" verip vermeyecekleri, evlerin sağlam olup olmadığı sorulmaktadır. İzleyenlere de sorular sorularak etkinliğe dâhil olmaları sağlanmaktadır. Evler inşa edilip denetlendikten sonra sallama tablası çocuklarla birlikte sallanarak küçük veya büyük depremler denenmektedir. Çocuklar denemeler sonunda kurallara uygun yapılan evlerin en büyük sallantıda bile yıkılmadığını gözlemlemektedirler.

Küçük gruplarda çocukların olumsuz etkilenmemeleri için aynı anda her iki grubun da evinin yıkılması veya yıkılmaması sağlanmalıdır. Yarışma heyecanıyla bu süreç kendiliğinden olması gerektiği gibi sonuçlanmaktadır. Çünkü ilk denemede çocuklar hızlı ev yapma heyecanı ile evlerin sağlam olmasına dikkat etmemektedirler. İkinci denemede gerekli uyarılar yapılarak doğru ipuçları verilmeli böylece aradaki farkı görmeleri sağlanmalıdır.

Daha büyük yaş gruplarında tablada salınım sırasında aynı anda hem kurallara uygun hem kurallara uygun olmayan bina gözlemlenebilir. Yine daha büyük yaş gruplarında tablada, deprem çözümlü farklı temel çeşitleri denenebilir, gözlem yapılabilir. Aynı tabla üzerinde farklı malzemeler ile (çöp şişler, tahta çubuklar... vb.) evler yapılabilir.

\section{2. "Yer Kabuğu Katman Modeli" ve "Üzerinde Yapı İnşa Edilebilen Deprem Sarsma Tablası Modeli" ile gerçekleştirilen AFAD eğitimlerinin etkilerinin değerlendirilmesi}

Yukarıda anlatılan öğretim materyallerinin kullanıldığı interaktif AFAD eğitimleri öncesinde çocuklara "deprem nedir?" diye sorulduğunda, "depremde evler yıkılır"," deprem evleri yıkar" gibi cevaplar alınırken; eğitim faaliyetlerinin sonunda çocukların tamamı "depremde sağlam olmayan evler yıkılır" demektedirler. Örneğin; 8 Şubat 2016 tarihinde AFAD Deprem Simülasyon Merkezi"ni ziyaret ederek bilinçlendirme eğitimine katılan Sincan Osman Ünyazıcı İlkokulu öğrencileri ve öğretmenleri, 25 Mart 2016'da ziyaret edilerek eğitimden sonra harekete geçip geçmedikleri yerinde gözlenmiştir (AFAD, Ocak 2017) (AFAD, Mart 2016). Sınıflardaki dolapların sabitlendiği ve her sınıf için deprem çantası hazırlandığı; ayrıca sınıfta sağlam ev yapma oyunları oynadıkları tahtalar, oyun hamuru, pipet, plastik çivi gibi malzemelerle yaptıkları evler görülmüştür. Hatta öğrenciler evlerinde aileleriyle birlikte yaptıkları afetlere hazırık ile ilgili faaliyetlerini AFAD Deprem Simülasyon merkezinin sosyal medya hesaplarında paylaşmışlardır. Bu okuldan eğitime katılan 4. Sınıf öğrencilerine uygulanan anketin verileri, öğrencilerin \%98'inin verilen mesajları doğru algıladıklarını ortaya koymaktadır. "Depremde evlerin yıkılma sebebi nedir?" sorusuna verilen açık uçlu cevapların tamamı "amaçlandığı" şekildedir. Bu soruya verilen cevapların bazıları şöyledir: "Sağlam olmamaları", "eksik malzeme kullanılması", "kurallara uygun yapılmaması", "evin yerinin uygun olmayışı", "temelinin iyi olmaması", "kötü yapılmış olması". Diğer okullarla yapılan çalışmalarda da benzer sonuçlar elde edilmiş; öğrenilenlerin aradan uzun zaman geçmesine rağmen unutulmadığı gözlenmiştir. Örneğin; Ankara Şeyh Şamil İlkokulu, Ankara Yahya Özsoy İşitme Engelliler Okulu gibi pek çok kurumun AFAD eğitimlerine katılan öğrencileri ve öğretmenleri ile eğitimin üzerinden 2-3 yıl geçtikten sonra görüşmeler yapılmış ve eğitimlerde öğrenilenlerin unutulmadığı belirlenmiştir. 


\section{Tartışma ve Sonuçlar}

Öğrenme sürecinde doğru araç gereçlerin kullanımının yararları, afet farkındalık eğitimlerinde somut olarak ortaya çıkmıştır. Soyutu somuta dönüştüren, görme ve dinlemenin yanı sıra deneyime dayalı öğrenme fırsatları sunan "Yer Kabuğu Katmanı" ve "Üzerinde Yapı İnşa Edilebilen Deprem Sarsma Tablası" modellerinin öğrenmeyi kolaylaştırdığı, unutmayı azalttığı ve hatırlama sağladığı görülmüştür.

$\mathrm{Bu}$ makaleye konu olan öğretim materyallerinin kullanıldığı AFAD eğitimleri öncesinde "deprem nedir? Depremde ne olur?" sorularına çocuklar; "depremde evler yıkılır, deprem evleri yıkar" gibi cevaplar vermektedirler. Eğitimden sonra ise tüm çocuklar "depremde sağlam olmayan evler yıkılı" şeklinde geri bildirim vermektedirler. Eğitimlerin ardından geçen 1-3 aylık zaman dilimlerinde ziyaret edilen okulların neredeyse tamamının harekete geçtiği gözlenmiştir. Sınıflardaki dolapların sabitlendiği ve her sınıf için deprem çantası hazırlandığı görülmüştür. Ayrıca bazı sınıflarda tahtalar, oyun hamuru, pipet, plastik çivi gibi malzemelerle sağlam ev yapma oyunları oynandığı tespit edilmiştir. Daha da önemlisi bazı öğrencilerin aileleri, evlerinde çocuklarıyla birlikte yaptıkları afetlere hazırlık faaliyetlerini AFAD Deprem Simülasyon merkezinin sosyal medya hesaplarında paylaşmışlardır.

Katıımcıların etkinliğe en üst düzeyde odaklanabilmeleri ve etkinliğe heyecan katılabilmesi için her iki aracın kullanımıyla ilgili farklı ders senaryoları üretilmiş ve makalede bu senaryolarla ilgili bilgiler verilmiştir. Ayrıca okul laboratuvarları ve sınıflar için bu modellerin daha küçük sürümlerinin üretimi hakkında ipuçları sunulmuştur.

Sonuç olarak, yeryüzünün en aktif deprem kuşaklarından birisi olan; Akdeniz, Alp, Himalaya deprem kuşağı içerisinde yer alan Ülkemizde, depremlerin en tahripkâr doğa kaynaklı afet olduğu görülmektedir. Depremleri önlememiz mümkün değildir ancak can ve mal kaybını önlemek, en aza indirmek toplumun bilinçlendirmekle mümkündür. Bu çerçevede; AFAD'ın yürüttüğü afet bilinçlendirme eğitimlerinin yaygınlaştırılması için gerekli önlemler alınmalıdır.

Millî Eğitim Bakanlığı, Yüksek Öğretim Kurumu, Gençlik ve Spor Bakanlığı başta olmak üzere çocuklar ve gençlerle ilgili kurumlar öncelikli olarak kurumlar arası iş birliği olanaklarının geliştirilmesi için gereği yapılmalıdır. Ulusal Afet Farkındalık ve Eğitim Merkezi ile özellikle riskli bölgeler ve iller düzeyinde bağlı şubeleri hızla kurularak yüz yüze eğitim faaliyetleri arttırımalıdır. Bunlara ek olarak, dijital ortamlar için benzer interaktif oyun platformları geliştirilmeli ve eğitimcilerin, ebeveynlerin çocuklarla birlikte kullanımına sunulmalıdır. 


\section{Kaynaklar}

AFAD. (2014, Kasım). Açıklamalı Afet Yönetimi Terimleri Sözlüğü. Eylül 25, 2018 tarihinde afad: https://www.afad.gov.tr/upload/Node/3495/xfiles/sozluk.pdf adresinden alındı

AFAD. (2015, Haziran 12). Ekim 27, 2018 tarihinde www.afad.gov.tr: https://www.afad.gov.tr/tr/1438/Afete-Hazir-Okullar-Odul-Aldi adresinden alındı

AFAD. (2016, Mart 04). Ekim 27, 2018 tarihinde afad.gov.tr: https://www.afad.gov.tr/tr/3617/Afete-Hazir-Turkiye-lle-Okullar-Harekete-Geciyor adresinden alındı

AFAD. (2016, Mayıs 31). https://www.afad.gov.tr/tr/4275/llkokul-Ogrencileri-Afete-HazirTurkiye-Icin-Tiyatro-Yapiyor. Ekim 27, 2018 tarihinde www.afad.gov.tr: https://www.afad.gov.tr/tr/4275/Ilkokul-Ogrencileri-Afete-Hazir-Turkiye-Icin-Tiyatro-Yapiyor adresinden alındı

AFAD. (2017, Ocak 25). Ekim 27, 2018 tarihinde www.afad.gov.tr: https://www.afad.gov.tr/tr/15362/AFAD-okullari-harekete-geciriyor adresinden alındı

AFAD. (2018). Hakkında. Eylül 25, 2018 tarihinde AFAD: https://www.afad.gov.tr/tr/2211/AFAD-Hakkinda adresinden alındı

AFADEM. (2014). https://ankara.afad.gov.tr/tr/4135/Deprem-Simulasyon-Merkezi.

Aghaei, N.; Seyedin, H.; Sanaeinasab, H. (2018). Strategies for disaster risk reduction education: A systematic review. J Educ Health Promot. 7: 98. doi: 10.4103/jehp.jehp_31_18

Atlı, A. (2006). Afet Yönetimi Kapsamında Deprem Açısından Japonya ve Türkiye Örneklerinde Kurumsal Yapılanma. Ankara: Asil Yayın Dağıtım.

Başbakanlık Türkiye Acil Durum Yönetimi Genel Müdürlüğü. (2003). Uluslararası Acil Durum Yönetimi Sempozyumu Sonuç Raporu. Ankara.

Dansereau, D.F. (1988). Learning and Study Strategies. 7 - Cooperative Learning Strategies. 103-120. https://doi.org/10.1016/B978-0-12-742460-6.50013-X

Demirel, Ö. (2012). Öğretme Sanatı (Öğretim İlke ve Yöntemleri). Ankara: PEGEM Akademi. Ekinci, N. (2011). İşbirliğine Dayalı Öğrenme. Ö. Ed: Demirel içinde, Eğitimde Yeni Yönelimler (s. 93-109). Ankara: PEGEM Akademi.

Ergünay, O. (2007). Türkiye'nin Afet Profili. TMMOB Afet Sempozyumu Bildiriler Kitabı (s. 114). Ankara: TMMOB İnşaat Mühendisleri Odası.

Gazi Üniversitesi Deprem Araştırma ve Uygulama Merkezi. (2007). Türkiye'nin Afet Profili. TMMOB AFET SEMPOZYUMU, (s. 1-14).

Guha-Sapir D, Vos F, Below R, with Ponserre S. (2011). Annual Disaster Statistical Review 2011: The Numbers and Trends. Brussels: CRED; 2012. http://www.cred.be/sites/default/files/ADSR_2011.pdf

Ivanov, A.; Cvetković, V. (2014). The Role Of Educatıon In Natural Disaster Risk Reduction. https://www.researchgate.net/publication/274954785_The_role_of_education_in_natural_dis aster_risk_reduction_-_Uloga_obrazovanja_u_smanjenju_rizika_od_katastrofa. 
Kadıoğlu, M. (2009). Eğitim Kurumları İçin Afet Acil Yardım Planlama Rehberi. İstanbul: İstanbul İl Afet ve Acil Durum Müdürlüğü.

Karamustafaoğlu, O. Ö. (2004). Isı ve sıcaklık kavramarının öğrencilerin zihninde yapılanmasına yönelik bir örnek olay incelemesi. Ondokuzmayıs Üniversitesi Eğitim Fakültesi Dergisi, 94-109.

Özden, Y. (2011). Öğrenme ve Öğretme. Ankara: PEGEM Akademi.

Şahinel, M. (2011). Etkin Öğrenme. Ö. Ed: Demirel içinde, Eğitimde Yeni Yönelimler (s. 149165). Ankara: PEGEM Akademi.

Quarantelli, E. L. (1985). What Is Disaster? The Need For Clarification In Definition And Conceptualization In Research. University of Delaware Disaster Research Center. URI: http://udspace.udel.edu/handle/19716/1119\#files-area

UNICEF, (2011). https://www.unicef.org/environment/files/DRRandEDbrochure.pdf

Vaughter, P. (2016). Unmaking Disasters: Education as a Tool for Disaster Response and Disaster Risk Reduction. POLICY BRIEF No. $6 . \quad 1-4$. https://collections.unu.edu/eserv/UNU:5705/PB6.pdf

Yalın, H. İ. (2004). Öğretim Teknolojileri ve Materyal Geliştirme. Ankara: Nobel Yayın Dağıtım.

https://www.afad.gov.tr/tr/1547/AFAD-Engel-Tanimiyor

https://www.afad.gov.tr/tr/1825/AFAD-ta-Isaret-Dili-ile-Deprem-Egitimi 